\title{
Revista Brasileira de Fruticultura \\ Flowering period and fruit quality of peach trees selections and cultivars in the metropolitan region of Curitiba
}

\author{
Giselda Alves ${ }^{1}$, Jhulia Gelain ${ }^{1}$, Gloria Soriano Vidal ${ }^{1}$, Cristiano Nunes Nesi ${ }^{2}$, \\ Louise Larissa May De Mio ${ }^{1}$, Luiz Antonio Biasi ${ }^{1}$
}

\begin{abstract}
This study aimed to evaluate the flowering period and the physicochemical characteristics of peaches, aiming to find those most promising for the diversification of the peach crop in the Metropolitan Region of Curitiba, Paraná State. We evaluated 8 selections and three cultivars in Porto Amazonas and 10 cultivars in Araucaria for flowering period, fruit set, diameter and height of fruit, average fruit weight, the skin color, soluble solids (SS), titratable acidity (TA), ratio SS/ $\mathrm{TA}$, hydrogen potential $(\mathrm{pH})$. The flowering period occurred between late June and late September ranging from 16 to 25 days. The fruit set rate was greater than $50 \%$ for 'Cascata 1513', 'Cascata 1429', 'Cascata 1577', 'Cascata 1743' and for all cultivars in Araucaria. There were significant differences for the other variables assessed. It was concluded that in Araucária, 'Charme' and 'Chimarrita' are good planting options, have the same duration of the cycle (111 days), being 'Charme' a little later. Besides these, 'Douradão' and 'Rubimel' have good fruit size, moderate acidity and best SS/TA ratio, being earlier than the previous ones. 'PS 25399' is the earliest and showed reddish epidermis and great consumer interest. In Porto Amazonas, selections and cultivars tested produced little fruit of small size, being required more studies to be recommended in these area.
\end{abstract}

Index terms: Prunus persica, stone fruits, fruit set, soluble solids.

\section{Período de florescimento e qualidade de frutos de seleções e cultivares de pessegueiro na região metropolitana de Curitiba}

Corresponding author: alves.giselda@gmail.com

Received: Janeiro 03, 2017. Accepted : October 02, 2017. Copyright: All the contents of this journal, except where otherwise noted, is licensed under a Creative Commons Attribution License.

\section{(cc) $\mathrm{EY}$}

Resumo - Objetivou-se avaliar o período de florescimento e as características físicas e químicas de frutos de pessegueiro, visando a encontrar aqueles mais promissores para a diversificação da persicultura na região metropolitana de Curitiba. Foram avaliados 8 seleções e três cultivares em Porto Amazonas e 10 cultivares em Araucária, quanto ao período de florescimento, frutificação efetiva, diâmetro e altura dos frutos, massa média de frutos, coloração da epiderme, sólidos solúveis (SS), acidez titulável (AT), relação SS/AT, potencial hidrogeniônico ( $\mathrm{pH}$ ). O período de floração ocorreu entre o final de junho e o final de setembro, com variação de 16 a 25 dias. A taxa de frutificação efetiva foi maior que 50\% para 'Cascata 1513', 'Cascata 1429', 'Cascata 1577', 'Cascata 1743 e para todas as cultivares avaliadas em Araucária. Verificaram-se diferenças significativas para as demais variáveis avaliadas. Concluiu-se que em Araucária 'Charme' e 'Chimarrita' continuam sendo boas opções de plantio na região, têm a mesma duração do ciclo (111 dias), sendo 'Charme' um pouco mais tardio. Além desses, 'Douradão' e 'Rubimel' apresentaram bom tamanho de fruto, melhor balanço entre sólidos solúveis e acidez moderada, e são mais precoces que as anteriores. 'PS 25399'é o cultivar mais precoce entre todas as avaliadas e apresenta epiderme avermelhada de grande interesse do consumidor. Em Porto Amazonas, as seleções e cultivares testadas produziram poucos frutos e de tamanho pequeno, sendo necessário mais estudo para recomendação nesta área.

Termos para indexação: Prunus persica, frutos de caroço, frutificação efetiva, sólidos solúveis. 


\section{Introduction}

Peach is one of the most cultivated fruit of temperate climate in the world, due to its adaptation to temperate and tropical zones. Paraná state was the fifth Brazilian producer in 2015 with 1.043 hectares, which produce 10.505 tons (IBGE, 2017), and the 'Chimarrita' was responsible for production expansion in the state (BIASI et al., 2004).

The introduction of new cultivars is an important item for the peach crop, but does not guarantee a satisfactory economic return because, besides the genetic factor, production and quality of the fruit also depends on the adaptability of the cultivar to environmental conditions. So the evaluation of selections and new cultivars in production regions is necessary (SIMONETTO et al., 2004; ALVES et al., 2012).

Among the many factors that influence the production, we highlight the weather conditions, mainly in relation to the amount of cold needed to overcome endodormancy of the cultivar (WAGNER JÚNIOR et al., 2009). Mild winters have been linked to heterogeneous flowering (COUTO et al., 2010), low budburst rate, reduced fruit set (ALVES et al., 2012). Once endodormancy is completed, the beginning of budbreak and flowering are regulated by warmer temperatures (CITADIN et al., 2001), period called ecodormancy. The time required between the entrance of the endodormancy and the flowering and budbreak vary between cultivars, and those with lower chilling requirement in mild winter regions allow the harvest of fruits in shorter supply times (BARBOSA et al., 2010).

Peach development is controlled by endogenous and environmental factors. Knowledge of plant responses to environmental variations (temperature, rainfall index, lightness) is important to improve fruit quality and yield (SILVA, et al., 2013). Peach cultivars are classified into five parameters, which are: (1) fruit pulp color, (2) chilling requirements to break dormancy, (3) time of occurrence of fruit ripening, (4) average fruit size and (5) fruit pulp quality. Size, soluble solids content, acidity and epidermis color are among the indexes influenced by light (DETONI et al., 2009) and are important to obtain cultivars with commercial characteristics for the fresh consumption (SILVA et al., 2013).

Therefore, this study aimed to evaluate the flowering period and physicochemical characteristics of fruits of peach tree cultivars and selections in function of the local edaphoclimatic conditions on the Metropolitan Region of Curitiba, aiming to find those most promising materials for the fruit production diversification in this region.

\section{Materials and methods}

The experiment was carried out at two commercial orchards, which were installed in 2012: Porto Amazonas, PR (25 $55^{\prime}$ 'South latitude, 49 $90^{\prime}$ 'West longitude and

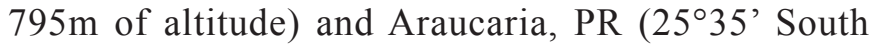
latitude, $49^{\circ} 24^{\prime}$ 'West longitude and $897 \mathrm{~m}$ of altitude). Monthly data of temperature, rainfall and chilling hours are shown in Table 1.

In Porto Amazonas were evaluated 8 selections ('Cascata 828', 'Cascata 1429', 'Cascata 1505', 'Cascata 1513', 'Cascata 1577', 'Cascata 1585', 'Cascata 1743' and 'Conserva 334') and three peach trees cultivars ('Early Gold', 'Galaxy' and 'Planalto') all on Okinawa rootstock. 'Cascata 828', 'Cascata 1743' and 'Galaxy' are subsp. platycarpa and the others are subsp. vulgaris.

In Araucaria were evaluated 10 cultivars ('Charme', 'Chimarrita', 'PS 25399', 'PS10711' and 'Rubimel' on 113 rootstock, and 'Douradão', 'Kampai', 'Oro Azteca', 'Texano' and 'Tropic Beauty' on Okinawa rootstock). The spacing used was $1.5 \mathrm{~m}$ between plants and $4.0 \mathrm{~m}$ between rows, the plants were conducted in $\mathrm{Y}$ conduction system. Thinning was done manually on all crop seasons between September and October, depending on each cultivar cycle. Plants received the cultural treatments recommended for the culture.

The experimental design was completely randomized with 11 treatments and two replications in Porto Amazonas and 10 treatments and four replications in Araucaria. Each plant was considered an experimental unit.

Flowering period was evaluated in the productive cycles of 2014/2015 and 2015/2016 by identification of the stages of: beginning of flowering (up to $10 \%$ open flowers), full bloom (50 to $70 \%$ open flowers) and end of flowering (less than $5 \%$ of flowers to open). For fruit set, 5 mixed branches of about $40 \mathrm{~cm}$ per plant were marked in the dormancy period and from full bloom the number of open flowers was wrote down. Approximately 30 days later, remaining fruits were counted and fruit set was calculated using the formula: fruit set $(\%)=$ (number of set fruits/ number of flowers) x 100 . The harvest peak also was evaluated (period with the highest number of fruit on harvest point).

Harvest was carried out according to the time of physiological maturity (considering the background color changing from green to light yellow or white-cream) of each selection or cultivar, which corresponded to the end of October to end of December. After harvest, fruits were taken to the laboratory to carry out the physicochemical assessments which occurred the day after the harvest. The following physical characteristics were measured: diameter and height of fruits, measured with a digital caliper placed perpendicular to the axis of the fruit, expressed in millimeters $(\mathrm{mm})$, average fruit weight, 
obtained by weighing the fruits, expressed in grams (g).

Epidermal color was assessed by the system registered by Commission International de I'Eclairage $\mathrm{L}^{*}, \mathrm{a}^{*}$ and $\mathrm{b}^{*}(C I E-L a b)$ : determined by electronic colorimeter, Minolta 300, with D 65 illuminant and $8 \mathrm{~mm}$ opening. In this color representation system, $\mathrm{L}^{*}, \mathrm{a}^{*}$ and $b^{*}$ values describe the uniformity of color in the threedimensional state, in which $\mathrm{L}^{*}$ represents bright dark (0, black, 100, white), $\mathrm{a}^{*}$ values correspond to the scale from green to $\left(a^{*}\right.$ negative, green color, $a^{*}$ positive, red color) and $\mathrm{b} *$ values correspond to the scale from blue to yellow ( $b^{*}$ negative, blue color, $b^{*}$ positive, yellow color). From these values, the angle Hue $\left(\mathrm{H}^{\circ}\right)$ was calculated by the formula $h^{o}=\tan ^{-1} b^{*} / a^{*}$. The readings were made on both sides of the fruit, being used 9 fruits per repetition.

The chemical characteristics of the fruits evaluated were: soluble solids (SS) determined with the aid of a refractometer with automatic temperature compensation and the results expressed in ${ }^{\circ} \mathrm{Brix}$, titratable acidity (TA) obtained by samples titration with $0.1 \mathrm{~N} \mathrm{NaOH}$ and results expressed in percentage (\%) of citric acid, SS/TA ratio, obtained by the ratio between the two variables above, hydrogen potential $(\mathrm{pH})$, determined in $\mathrm{pH}$ meter with automatic temperature compensation.

Data were submitted to analysis of variance and means were compared by the Scott-Knott test at 5\% probability, with the use of computer software R.

\section{Results and discussion}

\section{Porto Amazonas}

Flowering occurred in early July ('Cascata 828') and ended in the first half of September ('Galaxy' and 'Early Gold') (Figure 1). Early flowering cultivars are more likely to be damaged by frost, because according to the agro-climatic zoning done by Caramori et al. (2008), there is possibility of frost on the region until August 20, so the later flowering reduces the possibility of damage.

Full bloom occurred until July 15 to 'Cascata 828 ', until July 30 to 'Cascata 1429 ' and 'Cascata 1743', until August 10 to 'Cascata 1513' and 'Cascata 1505', until August 30 to 'Cascata 1577' and 'Cascata 1585', until September 5 to 'Conserva 334' and until September 10 to 'Galaxy', 'Early Gold' and 'Planalto'. The average time of flowering from the 2014/15 and 2015/16 crop seasons ranged from 17 to 28 days for most cultivars, except for 'Planalto' (11 days).

The observed changes for the beginning and end of flowering vary according to the number of chilling hours needed to overcome dormancy, and the time when temperature begins to increase, which promotes flowering and budburst of plants (SIMONETTO et al., 2004). Higher temperatures can induce the continuous floral bud development by altering the heat requirement.
Differences between cultivars and plants of the same cultivar in different treatments or locations are due to the breathing process which may continue in high rates under warm conditions (CHAVARRIA et al., 2009). In 2014 there was a greater accumulation of chilling hours $(\mathrm{CH})$, reaching $149 \mathrm{CH}$ until the 28th of August, while in 2015 only $89 \mathrm{CH}$ were accumulated (Table 1 ).

The Cascata 828 cultivar in addition to presenting the earliest flowering also showed the earliest harvest, with the harvest peak on October 20. The later selection was 'Cascata 1505 ' with peak harvest on December 12, while the other selections presented harvest in November.

Fruit set rate was higher in 'Cascata 1513' $(89.5 \%)$ and lowest in 'Planalto' (11.29\%) in the 2014/15 crop. In the following year, except for 'Cascata 1577 ' $(85.3 \%)$, all others presented set rate below $65 \%$ (Table 2), which may be related to less cold accumulation on this year.

There are also different variations in the production cycle, considering the beginning of flowering until the harvest peak. 'Galaxy' (83 days), 'Early Gold' (87 days), 'Conserva 334' (96 days), 'Cascata 1577' (107 days), 'Cascata 1513' (108 days) and 'Cascata 828' (109 days) presented the shortest production cycles. 'Cascata 1505', 'Cascata 1429', 'Cascata 1585', 'Cascata 1743' with $127,122,127,132$ days, respectively, presented longest production cycles. In addition, considering the maturation period, it can be inferred that, in the study region, 'Cascata 828 ' was early while the others were intermediate.

The average fruit weight was less than $60 \mathrm{~g}$ for most of the materials tested (Table 2), being classified within the caliber $3(51-56 \mathrm{~mm})$ and $2(45-51 \mathrm{~mm})$ according to the São Paulo program for the improvement of trade patterns and fresh produce packaging. Fruit size, considering the caliber and diameter, is the factor that determines the price (ALMEIDA; DURIGAN, 2006). Production, an important parameter for the future recommendation of cultivars, was not evaluated in the present study due to damages and the low number of fruits mainly in the 2014/15 crop, in which 'Planalto', 'Galaxy' 'Early Gold' and 'Cascata 1505 ' produced less than 10 fruits/plant.

There were significant differences for the diameter and height (Table 4) which shows different fruit shapes. Among the cultivars of the vulgaris subsp., there were rounded shape fruits, with the presence of a protruding apex in the selections 'Cascata 1429' and 'Cascata1577'. This characteristic can cause damage on the transportation (BASSETO et al., 2006) which may result in commercialization losses. Those of platycarpa subsp. presented flattened shape typical of the variety, highlighting 'Galaxy' that had larger fruits.

For $\mathrm{pH}$, soluble solids and titratable acidity, there were significant differences between the evaluated materials. The highest average $\mathrm{pH}$ was observed in 'Cascata 1505 ' (4.93) on 2014/15 crop season and in 'Cascata 1743 ' (4.35) on 2015/16 crop season, the lowest 
was in 'Conserva 334' (3.6), on both evaluated crop seasons. For titratable acidity there was a higher acidity in 'Early Gold' (0.97), 'Cascata 1505' (0.86), 'Cascata 1577 ' and 'Conserva 334' (0.72). Fruits with high acidity are more characteristic of those for industrial purpose, however, the cultivars tested do not have low acidity levels, even for fresh consumption. This may have been due to the influence of weather conditions and the location of the fruit on the plant (MATIAS et al., 2014).

The average levels of soluble solids (SS) in the fruits were, in general, higher in the 2014/15 season, probably due to excessive rainfall that occurred in the pre harvest period of the 2015/16 crop season (Table 1). The highest levels were found in 'Cascata $1585^{\prime}$ ' (11.6 Brix), 'Cascata $1743^{\prime}$ (11.4 ${ }^{\circ}$ Brix) and 'Planalto' (11.0 $0^{\circ}$ Brix), and the lowest in 'Cascata 1513' (8.4 Brix) and 'Conserva 334' $\left(8.7^{\circ}\right.$ Brix) (Table 4$)$. This study corroborates with Silva et al. (2013) who reported that white pulp peaches tend to have higher soluble solids than yellow pulp peaches.

The SS/TA ratio is indicative of fresh fruit maturity level, 'Cascata1585', 'Cascata 1743', 'Galaxy' and 'Planalto' showed the highest values of SS/AT. According to Costa et al. (2008), in general, this parameter can vary from 16.5 to 36.0 on peaches; a value of 25 or above is equivalent to optimum edible maturity, that is, of the tender fruit, if tritrable acidity is less than $0.5 \%$.

Regarding skin color represented by the hue angle $\left({ }^{\circ} \mathrm{H}\right)$ there was no difference between cultivars in the 2014/15 crop season. In the following season, the cultivars 'Conserva 334' and 'Cascata 828' differed significantly from the others with angles of near $90^{\circ}$, featuring more yellowish epidermis, especially in 'Conserva 334'.

\section{Araucária}

During the crops of 2014/15 and 2015/16, the flowering period of the cultivars occurred between late June and late September, being 'Kampai' the earliest and 'Texano' the latest. The same behavior was observed with these cultivars in relation to the harvest peak, where 'Kampai' at the earliest and 'Texano' later together 'Charme' (Figure 2). Generally, the full bloom occurred until July 15 for 'Kampai', until July 30 for 'Tropic Beauty' and 'Douradão', until August 10 for 'PS 25399', 'Rubimel' and 'Oro Azteca', until August 20 for 'PS 10711 ' and 'Chimarrita', until August 30 to 'Charme' and September 10 to 'Texano'. The average time of bloom in crops ranged from 19 to 26 days (Figure 2).

The fruit set rate among cultivars ranged from $54.26 \%$ ('Tropic Beauty') to 87.3 ('Texano') and between $51.5 \%$ ('Texano') to $65.13 \%$ ('Charme') for first and second season, respectively, with no significant differences between cultivars in this last season (Table 2). Peach usually has a high rate of fruit set, however the occurrence of frost between flowering and pit hardening and periods at temperatures above $20^{\circ} \mathrm{C}$ in pre-flowering can be harmful to fruit set (NAVA et al., 2009), climatic events that happen in this study area (Table 1).

The average fruit weight ranged from 44.60 to $63.98 \mathrm{~g}$ and from $91.15 \mathrm{~g}$ to $122.06 \mathrm{~g}$ for crop seasons 2014/15 and 2015/16 respectively. The larger fruits were 'Texano', 'Charme' and 'Rubimel', whereas the smaller were 'PS10711' 'PS25399 and 'Oro Azteca', for both evaluated crop seasons. Fruits had higher average weight in 2015/16 crop season, with the exception of 'Oro Azteca' (Table 2). 'Chimarrita' had a lower average weight than that observed in other studies (NIENOW; FLOSS, 2003; ALVES et al., 2012), especially in the 2014/15 crop, probably due to the greater number of fruits left on the plant after thinning.

In relation to the production cycle, 'PS 25399' and 'Texano', with 92 and 102 days, respectively, between the beginning of flowering and the peak of the harvest, presented the shortest cycle, and the highest was of 'Kampai' (125 days). The others were between 111 and 116 days. As for the maturation period, 'Kampai', 'Tropic Beauty' and 'PS 25399' were early, and the others were intermediate.

The diameter and height of the fruit, there were differences among cultivars in the evaluated crops (Table 3). 'Charme' and 'Texano' presented the fruits of larger diameter, but only in crop season 2015/16 they differed from all others. PS 10711, PS 25399 and Oro Azteca cultivars had diameters of less than $50 \mathrm{~mm}$ (Table 3 ) in the two years of evaluation, being classified as caliber 2 (45-51 mm). In the season 2015/16, 'Charme', 'Texano' and 'Rubimel' cultivars reached caliber 4 ( $>$ to 56 to $61 \mathrm{~mm}$ ) and can bring higher income to the producer. To Silva et al. (2013), the greater is the length, the greater is the diameter, however, this relationship was not observed in this study.

As for the $\mathrm{pH}$, 'Chimarrita' (4.2) had higher average in both 2014/15 and 2015/16 crop seasons, and the lowest was recorded in 'PS25399' (3.20) and 'Tropic Beauty' (3.1) in the first and second crop season, respectively. Works carried out by Ramos and Leonel (2008) and Leonel et al. (2011) also found differences in $\mathrm{pH}$ between cultivars. These differences may be related to the intrinsic cultivars characteristics (GONÇALVES et al., 2014).

There were differences among cultivars for the values obtained for the titratable acidity content and soluble solids (Table 3 ). The average levels of titratable acidity were higher in 2015/16 crop, ranging from $1.94 \mathrm{~g}$ ('Tropic Beauty') to $0.47 \mathrm{~g}$ ('Chimarrita') citric acid 100 g pulp ${ }^{-1}$, with the exception of 'Douradão' (0.61g) and 'Rubimel' (0.55g) (Table 3). The 'PS 25399', 'PS 10711' and 'Kampai' cultivars, classified for fresh consumption, showed, especially in the 2015/16 crop season, high acidity levels of $1.2,1.02,0.86 \mathrm{~g}$ citric acid $100 \mathrm{~g}^{\mathrm{p} u l p}$ 1 , respectively being considered, in this study, an acid cultivar . 
For total soluble solids values ranged from $11.41^{\circ}$ Brix ('Douradão') to $9.20^{\circ}$ Brix ('Texano') and from $11.71^{\circ}$ Brix ('Charme') to $8.50^{\circ}$ Brix (PS 25399) (Table 3). Soluble solids are important in determining the quality of the fruit, since they provide an indication of the amount of existing sugars in the fruit and may be associated with temperature variations and rainfall distribution (Table 1) and location of fruit on the plant (LEONEL et al., 2011).

The SS/TA ratio is important to evaluate the flavor of a fruit and indicates the degree of maturation (COMIOTTO et al., 2012), it is also related to acceptance of the fruit by the consumer. 'Chimarrita' followed by 'Charme', 'PS10711', 'Douradão' and 'Rubimel' showed values greater than 15. According to Mayer et al. (2008), the highest values of SS/TA ratio demonstrate the best palatability of the fruit for fresh consumption.

Regarding the skin color represented by Hue Angle $\left({ }^{\circ} \mathrm{H}\right)$, it was found that the fruits of 'PS10711', 'PS 25399', 'Texano' and 'Kampai' exhibited greater red coloration of the skin, therefore, smaller angles $(62.23,61.13,60.64$ and $54.01^{\circ}$ respectively) in the $2014 / 15$ season (Table 3 ). In the following season, the 'PS 25399' $\left(42.22^{\circ}\right)$ differed from the others presenting redder fruit. This feature is of great interest in the commercialization because, according to Trevisan et al. (2010), the preference of fresh peach consumers in three cities of the Rio Grande do Sul state was for peaches with reddish skin.

Table 1. Minimum, average and maximum temperatures $\left({ }^{\circ} \mathrm{C}\right)$, precipitation $(\mathrm{mm})$ and chilling hours $\left(\leq 7.2^{\circ} \mathrm{C}\right)$ from May to December 2014 and 2015.

\begin{tabular}{|c|c|c|c|c|c|c|c|c|}
\hline \multirow{2}{*}{ Climate data } & \multicolumn{8}{|c|}{ Araucária } \\
\hline & May & June & July & Aug & Sept & Oct & Nov & Dec \\
\hline & \multicolumn{8}{|c|}{2014} \\
\hline Minimum temp ${ }^{\circ} \mathrm{C}$ & 6.5 & -1.5 & 0.1 & 3.3 & 12.9 & 10.1 & 9.2 & 11.4 \\
\hline Average temp ${ }^{\circ} \mathrm{C}$ & 15.1 & 14.2 & 12.9 & 14.8 & 15.1 & 19.2 & 18.5 & 20.0 \\
\hline Maximum temp ${ }^{\circ} \mathrm{C}$ & 26.8 & 23.5 & 26.3 & 28.3 & 20.2 & 34.1 & 31.8 & 31.1 \\
\hline \multirow[t]{2}{*}{ Precipitation $(\mathrm{mm})$} & 97.8 & 320.6 & 32.2 & 63.6 & 204.4 & 64.8 & 173.0 & 226.2 \\
\hline & \multicolumn{8}{|c|}{2015} \\
\hline Minimum temp ${ }^{\circ} \mathrm{C}$ & 3.9 & -1.1 & 3.0 & 5.0 & 6.3 & 9.2 & 11.9 & 12.9 \\
\hline Average temp ${ }^{\circ} \mathrm{C}$ & 15.1 & 13.5 & 13.9 & 16.0 & 17.0 & 17.4 & 18.1 & 20.6 \\
\hline Maximum temp ${ }^{\circ} \mathrm{C}$ & 24.8 & 25.4 & 25.0 & 30.0 & 33.5 & 32.6 & 31.5 & 31.9 \\
\hline \multirow[t]{3}{*}{ Precipitation $(\mathrm{mm})$} & 87.0 & 74.4 & 203.0 & 13.4 & 131.2 & 130.4 & 160.4 & 140.4 \\
\hline & \multicolumn{8}{|c|}{ Porto Amazonas } \\
\hline & \multicolumn{8}{|c|}{2014} \\
\hline Minimum temp ${ }^{\circ} \mathrm{C}$ & 7.7 & -0.7 & 2.0 & 1.7 & 8.2 & 9.5 & 10.2 & 10.7 \\
\hline Average temp ${ }^{\circ} \mathrm{C}$ & 15.2 & 14.2 & 13.5 & 14.8 & 16.7 & 18.9 & 19.2 & 20.4 \\
\hline Maximum temp ${ }^{\circ} \mathrm{C}$ & 27.6 & 24.2 & 26.6 & 28.2 & 29.9 & 34.4 & 31.3 & 30.4 \\
\hline \multirow[t]{2}{*}{ Precipitation (mm) } & 97.8 & 320.4 & 32.2 & 63.6 & 126.8 & 64.8 & 173.0 & 226.2 \\
\hline & \multicolumn{8}{|c|}{2015} \\
\hline Minimum temp ${ }^{\circ} \mathrm{C}$ & 6.2 & -0.9 & 4.1 & 5.0 & 3.3 & 9.8 & 11.8 & 13.4 \\
\hline Average temp ${ }^{\circ} \mathrm{C}$ & 15.3 & 14.0 & 14.1 & 16.8 & 17.5 & 18.1 & 18.6 & 20.9 \\
\hline Maximum temp ${ }^{\circ} \mathrm{C}$ & 25.4 & 25.2 & 25.4 & 29.6 & 33.0 & 32.1 & 31.0 & 31.6 \\
\hline Precipitation (mm) & 93.6 & 95.0 & 22.02 & 39.0 & 208.2 & 163.2 & 252.8 & 275.8 \\
\hline Chilling hours $\left(\leq 7.2^{\circ} \mathrm{C}\right)$ in $2014^{*}$ & 0 & 39 & 63 & 47 & 0 & 0 & 0 & 0 \\
\hline Chilling hours $\left(\leq 7.2^{\circ} \mathrm{C}\right)$ in $2015^{*}$ & 9 & 22 & 37 & 6 & 15 & 0 & 0 & 0 \\
\hline
\end{tabular}

*Chilling hours were calculated with data from Lapa weather station.

Source: Instituto Tecnológico do Paraná (SIMEPAR) 


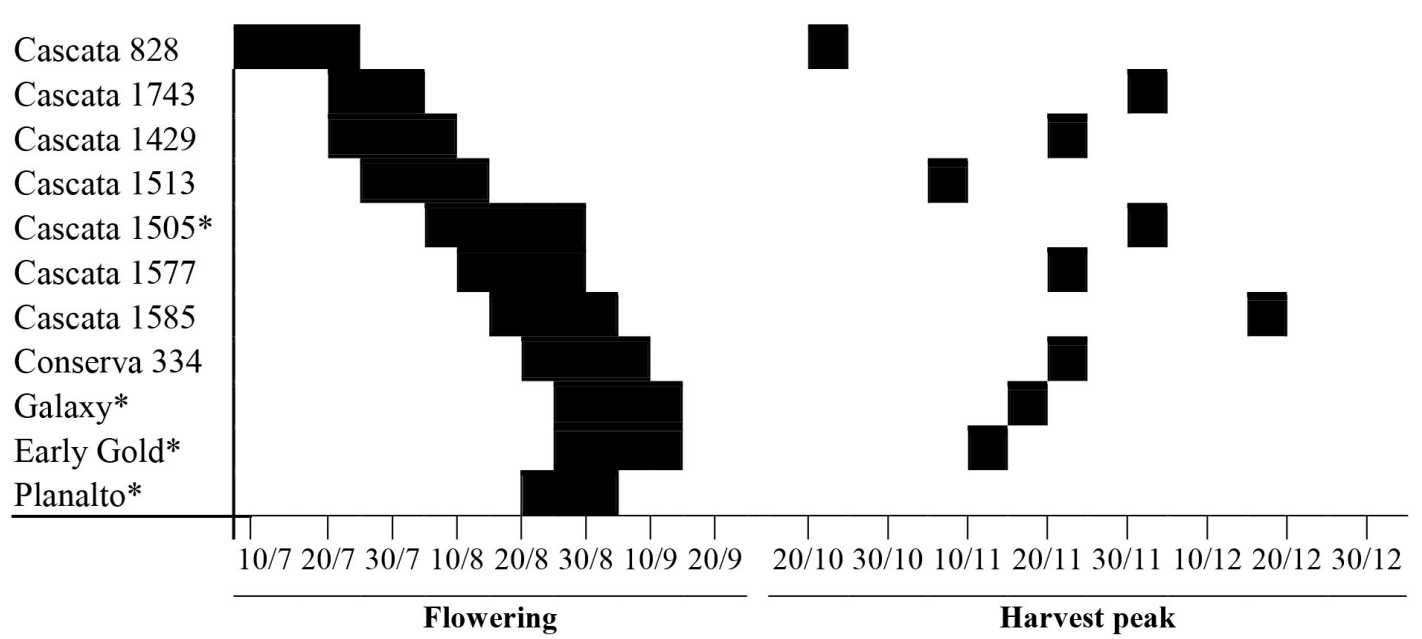

Figure 1. Flowering period and harvest peak recorded in 2014/15 and 2015/16 crops in cultivars and peach selections in Porto Amazonas, Parana State. 'Planalto', 'Galaxy', and 'Early Gold' are cultivars and the others are selections. *Considered harvest peak only the 2014/15 crop.

Table 2. Fruit set and average fruit weight of cultivars and selections of peach (Prunus persica) cultivated in Araucaria and Porto Amazonas, PR in 2014 and 2015.

\begin{tabular}{|c|c|c|c|c|}
\hline \multicolumn{5}{|c|}{ Araucária } \\
\hline \multirow[t]{2}{*}{ Cultivar } & \multicolumn{2}{|c|}{ Fruit set $(\%)$} & \multicolumn{2}{|c|}{ Average fruit weight (g) } \\
\hline & $2014 / 15$ & $2015 / 16$ & $2014 / 15$ & $2015 / 16$ \\
\hline Texano & $87.35 \mathrm{a}$ & $51.49 \mathrm{~ns}$ & $91.15 \mathrm{a}$ & $119.22 \mathrm{a}$ \\
\hline PS 10711 & $85.87 \mathrm{a}$ & 60.77 & $44.60 \mathrm{~b}$ & $69.00 \mathrm{c}$ \\
\hline Kampai & $84.48 \mathrm{a}$ & 54.96 & $77.67 \mathrm{a}$ & $90.34 b$ \\
\hline Rubimel & $83.48 \mathrm{a}$ & 60.37 & $82.80 \mathrm{a}$ & $105.38 \mathrm{a}$ \\
\hline Douradão & $82.50 \mathrm{a}$ & 60.41 & $70.62 \mathrm{a}$ & $103.76 \mathrm{a}$ \\
\hline Chimarrita & $81.57 \mathrm{a}$ & 62.78 & $77.52 \mathrm{a}$ & $92.23 b$ \\
\hline Oro Azteca & $79.96 a$ & 57.61 & $73.62 \mathrm{a}$ & $63.98 \mathrm{c}$ \\
\hline PS 25399 & $70.14 b$ & 56.74 & $45.54 b$ & $64.37 \mathrm{c}$ \\
\hline Charme & $59.99 b$ & 65.13 & $89.96 a$ & $122.06 \mathrm{a}$ \\
\hline Tropic Beauty & $24.26 \mathrm{c}$ & 56.82 & $60.31 \mathrm{~b}$ & $87.24 b$ \\
\hline C.V. \% & 11.63 & 14.92 & 16.81 & 15.07 \\
\hline \multicolumn{5}{|c|}{ Porto Amazonas } \\
\hline \multirow{2}{*}{ Cultivar } & \multicolumn{2}{|c|}{ Fruit set $(\%)$} & \multicolumn{2}{|c|}{ Average fruit weight $(\mathrm{g})$} \\
\hline & $2014 / 15$ & $2015 / 16$ & $2014 / 15$ & $2015 / 16$ \\
\hline Cascata 1513 & $89.55 \mathrm{a}$ & $64.59 \mathrm{~b}$ & $38.05 \mathrm{~d}$ & $54.18 \mathrm{~d}$ \\
\hline Cascata 1429 & $77.27 \mathrm{a}$ & $62.76 \mathrm{~b}$ & $65.96 \mathrm{c}$ & $71.47 \mathrm{c}$ \\
\hline Cascata 1585 & $74.59 \mathrm{a}$ & $43.56 \mathrm{c}$ & $94.13 \mathrm{a}$ & $87.06 \mathrm{~b}$ \\
\hline Galaxy & $73.76 \mathrm{a}$ & $40.02 \mathrm{c}$ & $74.01 \mathrm{~b}$ & - \\
\hline Cascata 1577 & $66.12 \mathrm{a}$ & $85.34 \mathrm{a}$ & $54.28 \mathrm{c}$ & $66.84 \mathrm{c}$ \\
\hline Cascata 1743 & $58.67 \mathrm{a}$ & $51.97 \mathrm{~b}$ & $44.25 \mathrm{~d}$ & $47.97 \mathrm{~d}$ \\
\hline Early Gold & $33.86 \mathrm{~b}$ & $33.73 \mathrm{c}$ & $29.88 \mathrm{~d}$ & - \\
\hline Cascata 1505 & $27.25 b$ & $59.68 \mathrm{~b}$ & $95.50 \mathrm{a}$ & $100.23 a$ \\
\hline Conserva 334 & $25.55 b$ & $55.41 \mathrm{~b}$ & $61.39 \mathrm{c}$ & $60.21 d$ \\
\hline Cascata 828 & $20.57 b$ & $30.41 \mathrm{c}$ & $30.88 \mathrm{~d}$ & $27.42 \mathrm{e}$ \\
\hline Planalto & $11.29 \mathrm{~b}$ & $22.98 \mathrm{c}$ & $99.91 \mathrm{a}$ & - \\
\hline$\overline{\text { C.V. } \%}$ & 22.78 & 15.2 & 16.34 & 12.24 \\
\hline
\end{tabular}

* Means followed by different letters in the same column differ by Skott Knott test at 5\% probability. 'Cascata 828', 'Cascata 1743' and 'Galaxy' are subsp. platycarpa and other subsp. vulgaris. 
Table 3. Physicochemical characteristics of peach fruit selections and cultivars in Araucaria, PR in 2014 and 2015.

\begin{tabular}{lccccccc}
\hline & \multicolumn{7}{c}{$2014 / 15$} \\
\cline { 2 - 8 } Cultivar & $\begin{array}{c}\text { Diameter } \\
(\mathrm{mm})\end{array}$ & $\begin{array}{c}\text { Height } \\
(\mathrm{mm})\end{array}$ & $\mathrm{pH}$ & $\begin{array}{c}\text { TTA } \\
(\% \text { citric ac })\end{array}$ & SST & SS/AT & Hue $^{\mathrm{o}}$ \\
\hline Charme & $54.26 \mathrm{a}$ & $52.98 \mathrm{a}$ & $3.92 \mathrm{~b}$ & $0.36 \mathrm{~b}$ & $11.01 \mathrm{a}$ & $30.4 \mathrm{~b}$ & $76.76 \mathrm{a}$ \\
Texano & $53.53 \mathrm{a}$ & $56.62 \mathrm{a}$ & $3.32 \mathrm{c}$ & $0.94 \mathrm{a}$ & $9.20 \mathrm{~b}$ & $9.9 \mathrm{~d}$ & $60.64 \mathrm{~b}$ \\
Rubimel & $51.28 \mathrm{a}$ & $54.34 \mathrm{a}$ & $3.96 \mathrm{~b}$ & $0.62 \mathrm{a}$ & $10.86 \mathrm{a}$ & $13.9 \mathrm{~d}$ & $73.39 \mathrm{a}$ \\
Kampai & $50.61 \mathrm{a}$ & $54.28 \mathrm{a}$ & $4.03 \mathrm{~b}$ & $0.70 \mathrm{a}$ & $11.06 \mathrm{a}$ & $13.5 \mathrm{~d}$ & $54.01 \mathrm{~b}$ \\
Chimarrita & $50.51 \mathrm{a}$ & $51.40 \mathrm{a}$ & $4.22 \mathrm{a}$ & $0.22 \mathrm{~b}$ & $10.81 \mathrm{a}$ & $47.2 \mathrm{a}$ & $74.41 \mathrm{a}$ \\
Oro Aztec & $49.84 \mathrm{a}$ & $54.65 \mathrm{a}$ & $3.30 \mathrm{c}$ & $0.81 \mathrm{a}$ & $9.74 \mathrm{~b}$ & $12.0 \mathrm{~d}$ & $68.67 \mathrm{a}$ \\
Douradão & $48.59 \mathrm{a}$ & $54.65 \mathrm{a}$ & $4.15 \mathrm{a}$ & $0.73 \mathrm{a}$ & $11.41 \mathrm{a}$ & $15.8 \mathrm{~d}$ & $79.21 \mathrm{a}$ \\
Tropic B. & $46.46 \mathrm{~b}$ & $44.38 \mathrm{~b}$ & $3.25 \mathrm{c}$ & $0.81 \mathrm{a}$ & $9.66 \mathrm{~b}$ & $12.2 \mathrm{~d}$ & $73.17 \mathrm{a}$ \\
PS 10711 & $45.50 \mathrm{~b}$ & $52.49 \mathrm{a}$ & $3.41 \mathrm{c}$ & $0.79 \mathrm{a}$ & $10.81 \mathrm{a}$ & $17.31 \mathrm{c}$ & $62.23 \mathrm{~b}$ \\
PS 25399 & $42.11 \mathrm{~b}$ & $41.69 \mathrm{~b}$ & $3.20 \mathrm{c}$ & $0.99 \mathrm{a}$ & $9.98 \mathrm{~b}$ & $10.1 \mathrm{~d}$ & $61.13 \mathrm{~b}$ \\
\hline C.V. \% & 7.1 & 6.7 & 3.3 & 29.2 & 4.3 & 17.6 & 11.0 \\
\hline & & & $2015 / 16$ & & & & \\
\hline Charme & $60.78 \mathrm{a}$ & $56.82 \mathrm{~b}$ & $3.80 \mathrm{~b}$ & $0.57 \mathrm{~d}$ & $11.71 \mathrm{a}$ & $20.3 \mathrm{a}$ & - \\
Texano & $58.88 \mathrm{a}$ & $62.67 \mathrm{a}$ & $3.28 \mathrm{e}$ & $1.55 \mathrm{a}$ & $8.86 \mathrm{~b}$ & $5.8 \mathrm{~d}$ & $68.68 \mathrm{a}$ \\
Rubimel & $56.16 \mathrm{~b}$ & $57.68 \mathrm{~b}$ & $4.08 \mathrm{a}$ & $0.55 \mathrm{~d}$ & $9.08 \mathrm{~b}$ & $16.3 \mathrm{~b}$ & $65.19 \mathrm{a}$ \\
Kampai & $54.65 \mathrm{~b}$ & $54.80 \mathrm{~b}$ & $3.66 \mathrm{c}$ & $0.86 \mathrm{c}$ & $9.10 \mathrm{~b}$ & $12.8 \mathrm{c}$ & $63.86 \mathrm{a}$ \\
Chimarrita & $52.83 \mathrm{c}$ & $50.64 \mathrm{c}$ & $4.17 \mathrm{a}$ & $0.47 \mathrm{~d}$ & $9.93 \mathrm{~b}$ & $20.7 \mathrm{a}$ & $64.25 \mathrm{a}$ \\
Oro Azteca & $48.21 \mathrm{c}$ & $53.44 \mathrm{c}$ & $3.43 \mathrm{~d}$ & $1.63 \mathrm{a}$ & $9.87 \mathrm{~b}$ & $6.5 \mathrm{~d}$ & - \\
Douradão & $56.81 \mathrm{~b}$ & $60.28 \mathrm{a}$ & $4.01 \mathrm{a}$ & $0.61 \mathrm{~d}$ & $10.00 \mathrm{~b}$ & $16.9 \mathrm{~b}$ & $62.56 \mathrm{a}$ \\
Tropic B. & $54.90 \mathrm{~b}$ & $48.23 \mathrm{~d}$ & $3.17 \mathrm{e}$ & $1.94 \mathrm{a}$ & $9.50 \mathrm{~b}$ & $4.9 \mathrm{~d}$ & $63.40 \mathrm{a}$ \\
PS 10711 & $49.42 \mathrm{c}$ & $51.84 \mathrm{c}$ & $3.85 \mathrm{~b}$ & $1.02 \mathrm{c}$ & $10.50 \mathrm{a}$ & $12.2 \mathrm{c}$ & $69.84 \mathrm{a}$ \\
PS 25399 & $49.92 \mathrm{c}$ & $45.45 \mathrm{~d}$ & $3.32 \mathrm{~d}$ & $1.20 \mathrm{~b}$ & $8.50 \mathrm{~b}$ & $7.45 \mathrm{~d}$ & $42.22 \mathrm{~b}$ \\
\hline C.V. \% & 5.5 & 4.8 & 2.6 & 25.5 & 9.6 & 18.0 & 12.2 \\
\hline
\end{tabular}

*Means followed by different letters in the same column differ by Skott Knott test at 5\% probability.

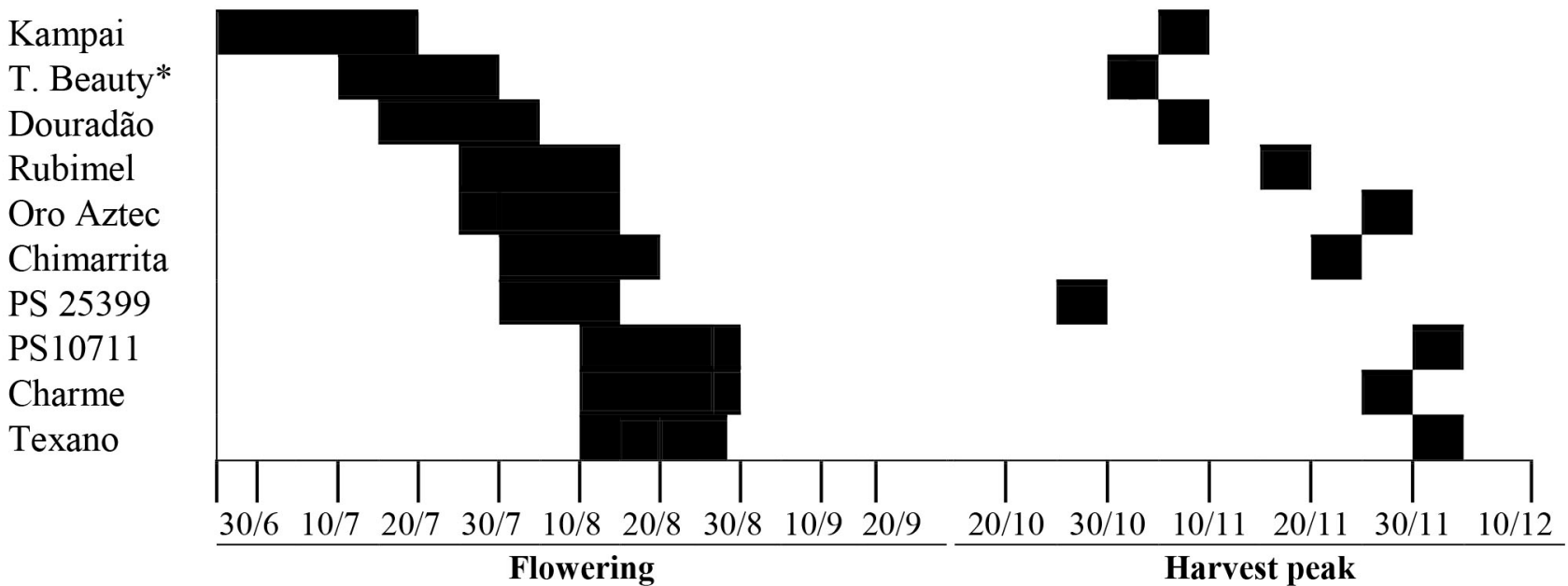

Figure 2. Flowering period and harvest peak recorded in 2014/15 and 2015/16 crops in peach cultivars in AraucariaPR. *Tropic Beauty. 
Table 4. Physico-chemical characteristics of peach fruit selections and cultivars in Porto Amazonas, PR in 2014 and 2015.

\begin{tabular}{|c|c|c|c|c|c|c|c|}
\hline \multirow[b]{2}{*}{ Cultivar } & \multicolumn{6}{|c|}{$2014 / 15$} & \multirow[b]{2}{*}{$\mathrm{Hue}^{\mathrm{o}}$} \\
\hline & $\begin{array}{c}\text { Diameter } \\
(\mathrm{mm})\end{array}$ & $\begin{array}{c}\text { Height } \\
(\mathrm{mm})\end{array}$ & $\mathrm{pH}$ & $\begin{array}{c}\text { TTA } \\
\text { (\% citric ac.) } \\
\end{array}$ & $\begin{array}{c}\text { SST } \\
\left({ }^{\circ} \text { Brix }\right) \\
\end{array}$ & SS/AT & \\
\hline Planalto & $65.58 \mathrm{a}$ & $79.54 \mathrm{a}$ & $4.45 \mathrm{c}$ & $0.28 \mathrm{e}$ & $11.03 \mathrm{a}$ & $39.23 \mathrm{~b}$ & $61.79 \mathrm{~ns}$ \\
\hline Conserva 334 & $59.61 \mathrm{~b}$ & $61.45 \mathrm{~b}$ & $3.60 \mathrm{f}$ & $0.68 \mathrm{~b}$ & $9.10 \mathrm{c}$ & $13.31 \mathrm{e}$ & 68.56 \\
\hline Galaxy & $58.05 \mathrm{~b}$ & $35.72 \mathrm{e}$ & $4.47 \mathrm{c}$ & $0.38 \mathrm{~d}$ & $10.50 \mathrm{~b}$ & $27.61 \mathrm{c}$ & 65.41 \\
\hline Cascata 1505 & $55.90 \mathrm{c}$ & $60.31 \mathrm{~b}$ & $4.93 \mathrm{a}$ & $0.53 \mathrm{c}$ & $10.30 \mathrm{~b}$ & $19.81 d$ & 50.84 \\
\hline Cascata 1585 & $55.06 \mathrm{c}$ & $55.22 \mathrm{c}$ & $4.74 \mathrm{~b}$ & $0.16 \mathrm{f}$ & $11.61 \mathrm{a}$ & $68.82 \mathrm{a}$ & 58.36 \\
\hline Cascata 1429 & $51.24 \mathrm{c}$ & $53.93 \mathrm{c}$ & $4.10 \mathrm{e}$ & $0.46 \mathrm{c}$ & $9.32 \mathrm{c}$ & $21.16 \mathrm{~d}$ & 60.78 \\
\hline Cascata 1743 & $53.07 \mathrm{c}$ & $30.01 \mathrm{f}$ & $4.44 \mathrm{c}$ & $0.28 \mathrm{e}$ & $11.44 \mathrm{a}$ & $40.19 b$ & 63.01 \\
\hline Cascata 1577 & $45.68 \mathrm{~d}$ & $44.55 \mathrm{~d}$ & $4.28 \mathrm{~d}$ & $0.34 \mathrm{e}$ & $9.95 \mathrm{~b}$ & $29.11 \mathrm{c}$ & 47.77 \\
\hline Cascata 828 & $42.30 \mathrm{~d}$ & $26.56 \mathrm{f}$ & $3.74 \mathrm{f}$ & $0.62 \mathrm{~b}$ & $8.42 \mathrm{c}$ & $13.57 \mathrm{e}$ & 51.13 \\
\hline Cascata 1513 & 39.45 e & $42.76 \mathrm{~d}$ & $4.58 \mathrm{c}$ & $0.46 \mathrm{c}$ & $8.72 \mathrm{c}$ & $18.88 \mathrm{~d}$ & 58.77 \\
\hline Early Gold & $36.38 \mathrm{e}$ & $41.47 \mathrm{~d}$ & $3.71 \mathrm{f}$ & $0.97 \mathrm{a}$ & $8.80 \mathrm{c}$ & $13.31 \mathrm{e}$ & 63.73 \\
\hline C.V. $\%$ & 5.6 & 8.1 & 2.8 & 12.3 & 4.3 & 23.1 & 19.1 \\
\hline \multicolumn{8}{|c|}{$2015 / 16$} \\
\hline Conserva 334 & $58.33 \mathrm{a}$ & $59.70 \mathrm{a}$ & $3.69 \mathrm{c}$ & $0.72 \mathrm{a}$ & $8.77 \mathrm{~d}$ & $12.22 \mathrm{c}$ & $71.98 \mathrm{~b}$ \\
\hline Cascata 1505 & $56.00 \mathrm{a}$ & $58.82 \mathrm{a}$ & $3.88 \mathrm{~b}$ & $0.86 \mathrm{a}$ & $11.02 \mathrm{a}$ & $12.82 \mathrm{c}$ & $54.74 \mathrm{a}$ \\
\hline Cascata 1585 & $51.93 \mathrm{~b}$ & $55.53 \mathrm{~b}$ & $4.24 \mathrm{a}$ & $0.44 \mathrm{~b}$ & $10.11 \mathrm{~b}$ & $22.98 \mathrm{a}$ & $43.55 b$ \\
\hline Cascata 1743 & $51.10 \mathrm{~b}$ & $27.10 \mathrm{~d}$ & $4.35 \mathrm{a}$ & $0.58 \mathrm{~b}$ & $11.37 \mathrm{a}$ & $19.47 b$ & $55.78 b$ \\
\hline Cascata 1429 & $51.07 \mathrm{~b}$ & $54.08 \mathrm{~b}$ & $4.14 \mathrm{a}$ & $0.43 \mathrm{~b}$ & $9.69 \mathrm{c}$ & $23.40 \mathrm{a}$ & $52.98 \mathrm{~b}$ \\
\hline Cascata 1577 & $49.01 \mathrm{~b}$ & $48.66 \mathrm{c}$ & $3.94 \mathrm{~b}$ & $0.72 \mathrm{a}$ & $9.54 \mathrm{c}$ & $13.27 \mathrm{c}$ & $54.51 \mathrm{~b}$ \\
\hline Cascata 1513 & $44.67 \mathrm{c}$ & $47.89 \mathrm{c}$ & $4.28 \mathrm{a}$ & $0.44 \mathrm{~b}$ & $8.45 \mathrm{~d}$ & $19.41 b$ & $56.38 b$ \\
\hline Cascata 828 & $41.38 \mathrm{c}$ & $24.94 \mathrm{~d}$ & $3.84 \mathrm{~b}$ & $0.82 \mathrm{a}$ & $10.87 \mathrm{a}$ & $13.47 \mathrm{c}$ & $65.59 a$ \\
\hline C.V. \% & 5.0 & 4.9 & 2.6 & 11.9 & 4.9 & 18.0 & 12.5 \\
\hline
\end{tabular}

*Means followed by different letters within the same column differ by Skott Knott test at 5\% probability. 'Planalto', 'Galaxy', 'Early Gold' are cultivars and the others are selections. 'Cascata 828', 'Cascata 1743' and 'Galaxy' are subsp. platycarpa and other subsp. vulgaris. 


\section{Conclusions}

In the adopted experimental conditions, it was concluded that:

1-In Araucária, Charme and Chimarrita cultivars are good planting options, have the same duration of the cycle (111 days), being 'Charme' slightly later. Douradão and Rubimel have good fruit size, moderate acidity and best SS/TA ratio, being earlier than the previous ones. Besides these, 'PS 25399' is the earliest and showed reddish epidermis and great consumer interest.

2-In Porto Amazonas, selections and cultivars tested produced little fruit of small size, being required more studies to be recommended in these area.

\section{Acknowledgment}

To Mr. Waldomiro Gayer Neto, Araucaria, and Agropecuária Boutin, Porto Amazonas, for granting areas for the installation of the experiments, and to EMBRAPA for providing selections and peach cultivars for the experiment of Porto Amazonas.

\section{References}

ALMEIDA, G.V.B.; DURIGAN, J.F. Relação entre as características químicas e o valor dos pêssegos comercializados pelo sistema veiling frutas Holambra em Paranapanema-SP. Revista Brasileira de Fruticultura, Jaboticabal, v.28, n.2, p. 218-221, 2006.

ALVES, G.; SILVA, J.; MAY DE MIO, L.L.; BIASI, L.A. Comportamento fenológico e produtivo de cultivares de pessegueiro no município da Lapa, Paraná. Pesquisa Agropecuária Brasileira, Brasília, DF, v.47, n.11, p.1596-1600, 2012.

BARBOSA, W.; CHAGAS, E.A.; POMMER, C.V.; PIO, R. Advances in low-chilling peach breeding at Instituto Agronômico, São Paulo State, Brazil. Acta Horticulturae, Leuven, v.872, p.147-150, 2010.

BASSETTO, E.; AMORIM, L.; MARTINS, M. C.; FERREIRA, M. D. ; GUTIERREZ, A.S.D.; LOURENÇO, S.A.Assessment of diseases and injuries of peaches during different phases of postharvest. Acta Horticulturae, v. 713, p. 397-400, 2006.
BIASI, L. A.; ZANETTE, F.; PETRI, J. L.; MARODIN, G.A.B. Cultivares de fruteiras de caroço. In: MONTEIRO, L.B.; MAY DE MIO, L.L.; SERRAT, B.M.; CUQUEL, F.L. (Ed.). Fruteiras de caroço: uma visão ecológica. Curitiba: UFPR, 2004. p.5-32.

CARAMORI, P.H.; CAVIGLIONE, J.H.; WREGE, M.S.; HERTER, F.G.; HAUAGGE, R.; GONÇALVES, S.L.; CITADIN, I.; RICCE, W.S. Zoneamento agroclimático para o pessegueiro e a nectarineira no Estado do Paraná. Revista Brasileira de Fruticultura, Jaboticabal, v.30, n.4, p.1040-1044, 2008.

CHAVARRIA, G.; HERTER, F.G.; RASEIRA, M.C.B.; RODRIGUES, A.C.; REISSER, C.; SILVA, J.B Mild temperatures on bud breaking dormancy in peaches. Ciência Rural, Santa Maria, v. 39, n.7, p. 2016-2021, 2009.

CITADIN, I.; RASEIRA, M.C.B.; HERTER, F.G.; SILVA, J.B. Heat requirement for blooming and leafing in peach. HortScience, Alexandria, v. 36, n. 2, p. 305-307, 2001.

COMIOTTO, A., FACHINELLO, J.C., HOFFMANN, A., MACHADO, N.P., GALARÇA, S.P., BETEMPS, D.L. Vigor, floração, produção e qualidade de pêssegos 'Chimarrita' e 'Maciel' em função de diferentes portaenxertos. Ciência Rural, Santa Maria, n.42, p.788-794, 2012.

COSTA, S.M.; MANOEL, L.; MOREIRA, G.C.; VIEITES, R.L.; LIMA, L.C.; PALLAMIN, M.L. Conservação frigorificada de pêssegos 'Tropic Beauty' irradiados. Revista Iberoamericana de Tecnologia Postcosecha, Toluca, v. 9, n. 2, p. 131-137, 2008.

COUTO, M.; RASEIRA, M.C.B.; HERTER, F.G.; SILVA, J.B. Influence of high temperatures at blooming time on pollen production and fruit set of peach cvs. Maciel and Granada. Acta Horticulturae, Leuven, v.872, p.225-230, 2010 .

DETONI, A.M.; HERZOG, N.F.M.; OHLAND, T.; KOTZ, T.; CLEMENTE, E.; Influência do sol nas características físicas e químicas da tangerina Ponkan cultivada no Oeste do Paraná. Revista Ciência e Agrotecnologia, Lavras, v. 33, n. 2, p. 624-628, 2009.

GONÇALVES, M.A.; PICOLOTTO, L.; AZEVEDO, F.Q.; COCCO, C.; ANTUNES, L.E.C. Qualidade de fruto e produtividade de pessegueiros submetidos a diferentes épocas de poda. Ciência Rural, Santa Maria, v.44, n.8, p.1334-1340. 2014 
IBGE - Instituto Brasileiro de Geografia e Estatística. Produção agrícola municipal. Rio de Janeiro, 2017. Disponível em: $\leq$ https://sidra.ibge.gov.br/tabela/1613>. Acesso em: 05 maio 2017.

LEONEL, S.; PIEROZZI, C.G.; TECCHIO, M.A. Produção e qualidade dos frutos de pessegueiro e nectarineira em clima subtropical do estado de São Paulo. Revista Brasileira de Fruticultura, Jaboticabal, v.33, n.1, p.118-128, 2011.

MATIAS, R.G.P.; RIBEIRO, M.R.; SILVA, D.F.P.; SILVA, J.O.C.; OLIVEIRA, S.P.; BRUCKNER, C.H. Características físicas e químicas de pêssego em função da altura de inserção na planta. Comunicata Scientiae, Bom Jesus, v.5, n.4, p.435-440, 2014.

MAYER, N.A.; MATTIUZ, B.; PEREIRA, F.M. Qualidade pós-colheita de pêssegos de cultivares e seleções produzidos na microrregião de Jaboticabal-SP. Revista Brasileira de Fruticultura, Jaboticabal, v.30, n.3, p.616-621, 2008.

NAVA, G.A.; MARODIN, G.A.B.; SANTOS, R.P. Reprodução do pessegueiro: efeito genético, ambiental e de manejo das plantas. Revista Brasileira de Fruticultura, Jaboticabal, v.31, n.4, p.1218-1233, 2009.

NIENOW, A.A.; FLOSS, L.G. Produção de pessegueiro e nectarina no planalto médio do Rio Grande do Sul em anos de inverno ameno. Ciência Rural, Santa Maria, v.33, n.2, p.241-246, 2003.
RAMOS, D.P.; LEONEL, S. Características dos frutos de cultivares de pessegueiros e de nectarineira, com potencial de cultivo em Botucatu, SP. Bioscience Journal, Uberlândia, v.24, p.10-18, 2008.

SILVA, D.F.P.; SILVA, J.O.C.; MATIAS, R.G.P.; RIBEIRO, M.R.; BRUCKNER, C.H. Correlação entre características quantitativas e qualitativas de frutos de pessegueiros na geração $\mathrm{F} 2$ cultivadas em região subtropical. Revista Ceres, Viçosa, MG, n.60, p.53-58, 2013.

SIMONETTO, P.R.; FIORAVANÇO, J.C.; GRELLMANN, E.O. Avaliação de algumas características fenológicas e produtivas de dez cultivares e uma seleção de pessegueiro em Veranópolis, RS. Revista Brasileira de Agrociência, Pelotas, v.10, n.4, p.427- 43, 2004.

TREVISAN, R.; PIANA, C.F.B.; TREPTOW, R.O.; GONÇALVES, E.D.; ANTUNES, L.C.C. Perfil e preferências do consumidor de pêssego (Prunus persica) em diferentes regiões produtoras no Rio Grande do Sul. Revista Brasileira de Fruticultura, Jaboticabal, v.32, n.1, p.90-100, 2010.

WAGNER JÚNIOR, A.; BRUCKNE,R C.H.; SALOMÃO, L.C.C.; PIMENTEL, L.D.; SILVA, J.O.C.; SANTOS, C.E.M. Avaliação da necessidade de frio de pessegueiro por meio de ramos enxertados. Revista Brasileira de Fruticultura, Jaboticabal, v.31, n.4, p.1054-1059, 2009. 